\section{artelogie}

\section{Artelogie}

Recherche sur les arts, le patrimoine et la littérature de l'Amérique latine

$12 \mid 2018$

Idiosyncrasie de l'indigénisme en Amérique latine.

Pluralité des sources et des appropriations extra-

latino-américaines

\title{
Corporate photography goes to the forest
}

\section{Mariana von Hartenthal}

\section{(2) OpenEdition \\ 1 Journals}

Electronic version

URL: http://journals.openedition.org/artelogie/2181

DOI: $10.4000 /$ artelogie. 2181

ISSN: 2115-6395

Publisher

Association ESCAL

\section{Electronic reference}

Mariana von Hartenthal, «Corporate photography goes to the forest », Artelogie [Online], 12 | 2018

Online since 07 September 2018, connection on 01 May 2019. URL : http://journals.openedition.org/ artelogie/2181; DOI : 10.4000/artelogie. 2181

This text was automatically generated on 1 May 2019.

Association ESCAL 


\title{
Corporate photography goes to the forest
}

\author{
Mariana von Hartenthal
}

\section{Introducción}

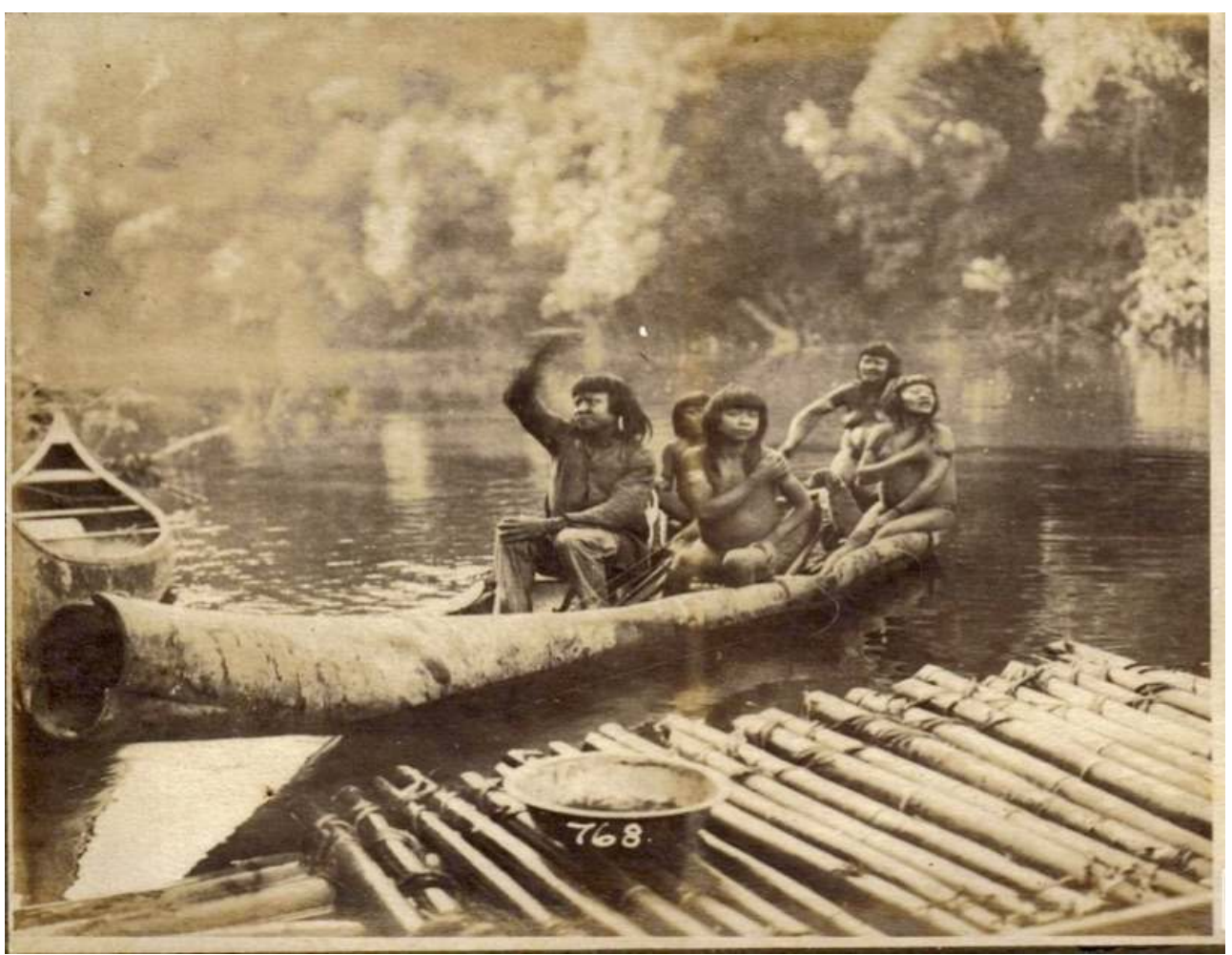

Figure 1: Photograph 768 by Dana Merrill, 1909-1911. Gelatin silver print (NYPL).

In the photograph (figure 1), we see five people in a bark canoe on a river. An unruly vegetable mass covers the background, meeting the water in a diffuse, glistening mist. On 
the left, there is another, empty canoe, with a pointy bow. In the foreground, a metal bowl rests on a bamboo raft. We clearly see the watermark on the canoe, the texture of the bark, the fiber ropes that tie the logs of the raft together. The image sharpness and clarity of details attest the photographer's skill. The diagonal line of the bamboo raft run toward the canoe's watermark in a dynamic composition that contrasts with the fuzzy vegetation and guides our eyes to the people in the center of the image. The man in front of the group wears a buttoned shirt and checkered pants; the others wear only armbands or waistbands. They all have straight, long hair with bangs, and look at different directions. The man in shirt and pants waves his right hand in the air and looks up front, to our left. The one next to him, the only person directly facing the camera, places his right hand on the left shoulder and rests his left hand on the thigh, in an awkward gesture. The woman behind him seems to emulate his posture. Next to her and hard to devise in a cursory glance, a little dog with long, floppy ears stands on his back legs.

2 The handwritten number "768" identifies the photograph taken by Dana B. Merrill (1877-?), a New York-based photographer hired to document the construction of the Madeira-Mamoré Railway (MMR). ${ }^{1}$ The line was built between 1907 and 1912 in the Brazilian Amazon (now in the State of Rondônia), to connect Bolivia's agricultural, mining, and rubber production to the Amazon basin, and hence to the Atlantic Ocean. Transportation in the Amazon traditionally relies on rivers, but rapids made the Madeira and the Mamoré impassible by ship, so the MMR was devised to circumvent the unruly waters. A Company spearheaded by American entrepreneur Percival Farquhar (1864-1953) directed workers coming from Brazil and abroad, especially the Caribbean, to complete the challenging job. In Brazil, the MMR became known as "The Devil's Railroad" due to the appalling death toll of its workers. ${ }^{2}$ By the time of its inauguration, Asian rubber plantations had already supplanted South American production, and the MMR proved an economic failure. In 1937 the Brazilian government rescinded the contract and nationalized the line. In the $1960 \mathrm{~s}$, as the country shifted to automotive transportation, the MMR was replaced by highway BR-364. It was finally deactivated in 1972.

We know little about Dana Bertran Merrill. He was born in Grafton County, New Hampshire in 1877, but no one has been able to determine his death date. ${ }^{3}$ Former MMR employees mention his photographic studio in Manhattan until the 1940s. Merrill sold prints of his images to colleagues while in Brazil and after he returned to the United States as he carried some MMR negatives with him as duplicates and originals. These photographs comprise the majority of images in MMR collections, housed in institutions in the United States and Brazil. With the exception of around two hundred glass and film negatives (now at the Museu Paulista, in São Paulo, and at the National Library in Rio de Janeiro), most of the ones he left at the MMR Company in Brazil have been lost. Unlike most corporate photographers working in the United States at his time, Merrill was not an outside observer, but a full participant in the everyday life of the people he photographed, as he lived in Rondônia for at least one year. He documented not only the construction works but various aspects of the MMR workers' village, Porto Velho, and in camps. Although not frequent, encounters with the native population were part of life in the MMR complex, and as such were registered by the photographer. Another particularity of the MMR coverage is the freedom apparently allowed to the photographer. Landmark studies on corporate imagery (NYE 1985; MARCHAND 1998; BROWN 2005) tend to view such visual projects as inherently imposed from above. ${ }^{4}$ They presuppose tightly controlled assignments closely directed by human resources or public 
relations departments. This does not seem to be the case with Merrill, whose varied and informal coverage of the MMR suggests he worked under little supervision or strict guidance. Thus, even though an image of Amazonians on a canoe does not correspond to what we normally expect from corporate photography, that is precisely what 768 is. Images such as this one and other pictures of Amerindians by Merrill demonstrate the diversity of corporate imagery, especially when it comes to transnational contexts and less industrialized economies.

As Elspeth Brown (2005) has noted, between 1880 and 1920 American corporate photographic conventions were still being delineated, and professionals like Merrill adapted existing visual vocabularies to their needs. This article discusses how Merrill's portrayals of Amerindians dialogued with earlier traditions of depicting indigeneity, especially the visuality of the Noble Savage, a way of seeing that sought for a supposedly "pure Indian," one untouched by western culture. I examine how authors have produced the "purity" of the Madeira and Mamoré native population by deploying "markers of typicality" (PINNEY 1997: 53) - bows and arrows, bark canoes, and nakedness - since the first reports on the area appeared in the eighteenth century. ${ }^{5}$ I then discuss Merrill's adoption of such markers of typicality in his photographic documentation, and suggest that, while in Brazil, the photographer accepted the hybrid reality of the Amerindians he met. He registered, and sometimes even emphasized, material culture that demonstrated their contact with westerners.

\section{The imagined human geography of the Madeira and Mamoré Valley}

Merrill's photographs were not kept hidden in the MMR Company's offices, but circulated more broadly due to American employees' writing and collecting practices. A few employees wrote about their experiences in Brazil: in 1910, engineer Herbert Lome wrote an article for World's Work. The following year, engineer P. H. Ashmead published a text in the Bulletin of the Pan American Union; and in 1928, engineer John J. Bayliss wrote his MMR recollections for Stone and Webster Journal. In 1940, Frank Kravigny, who worked as a clerk at the MMR, wrote the memoir The Jungle Route. Except for Lome, mostly concerned with the "American Sanitary Triumph" in the Amazon, all others illustrated their texts with Merrill's photographs of Amerindians. 768 appears in Bayliss's recollections, captioned "Arawaks" (1928: 194), and another image of Amerindians on a canoe is reproduced in Ashmead's account for the Bulletin (1911: 437; figure 2). Kravigny chose ten pictures of Amazonians, including 768, for his book. Images of Brazilian natives were also cherished by men who did not publish their impressions but still gathered mementoes of their time building the MMR. They appear in all former employees' collections, and Merrill himself selected seventeen photographs of Amerindians for the album he put together, now at the New York Public Library (NYPL; figure 3). We cannot consider the ubiquity of pictures of Amerindians as a mere reflection of Americans' curiosity about the Other. In comparison, images and written comments about Caribbean workers rarely appear in MMR archives, even though they made up the majority of the workforce. Instead, it was "the Indian," a character closely associated with the Brazilian wilderness, who captured Americans' attention. 


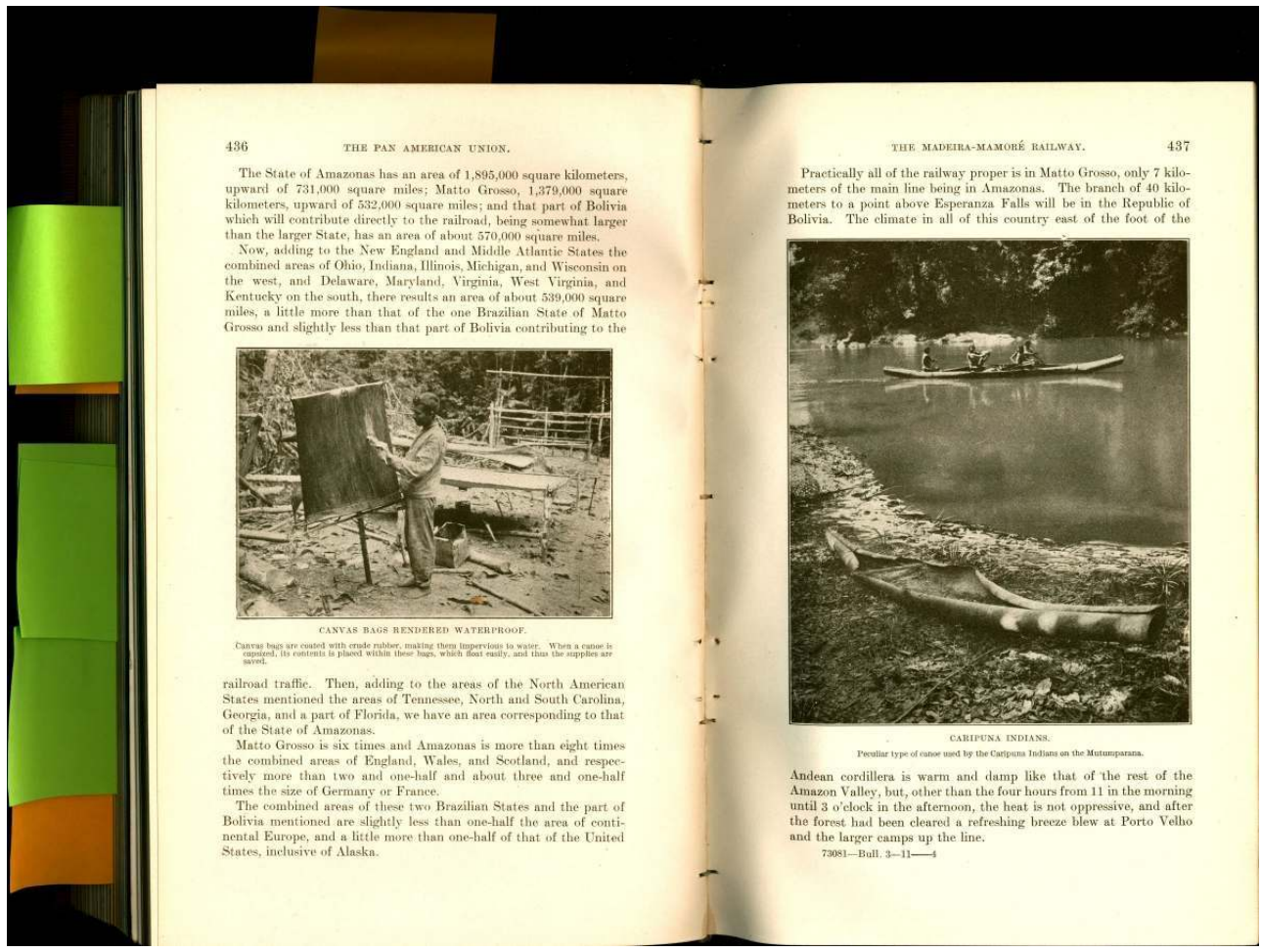

Figure 2: Photograph by Dana Merrill, 1909-1911. Reproduced in Ashmead's account for the Bulletin (1911: 437).

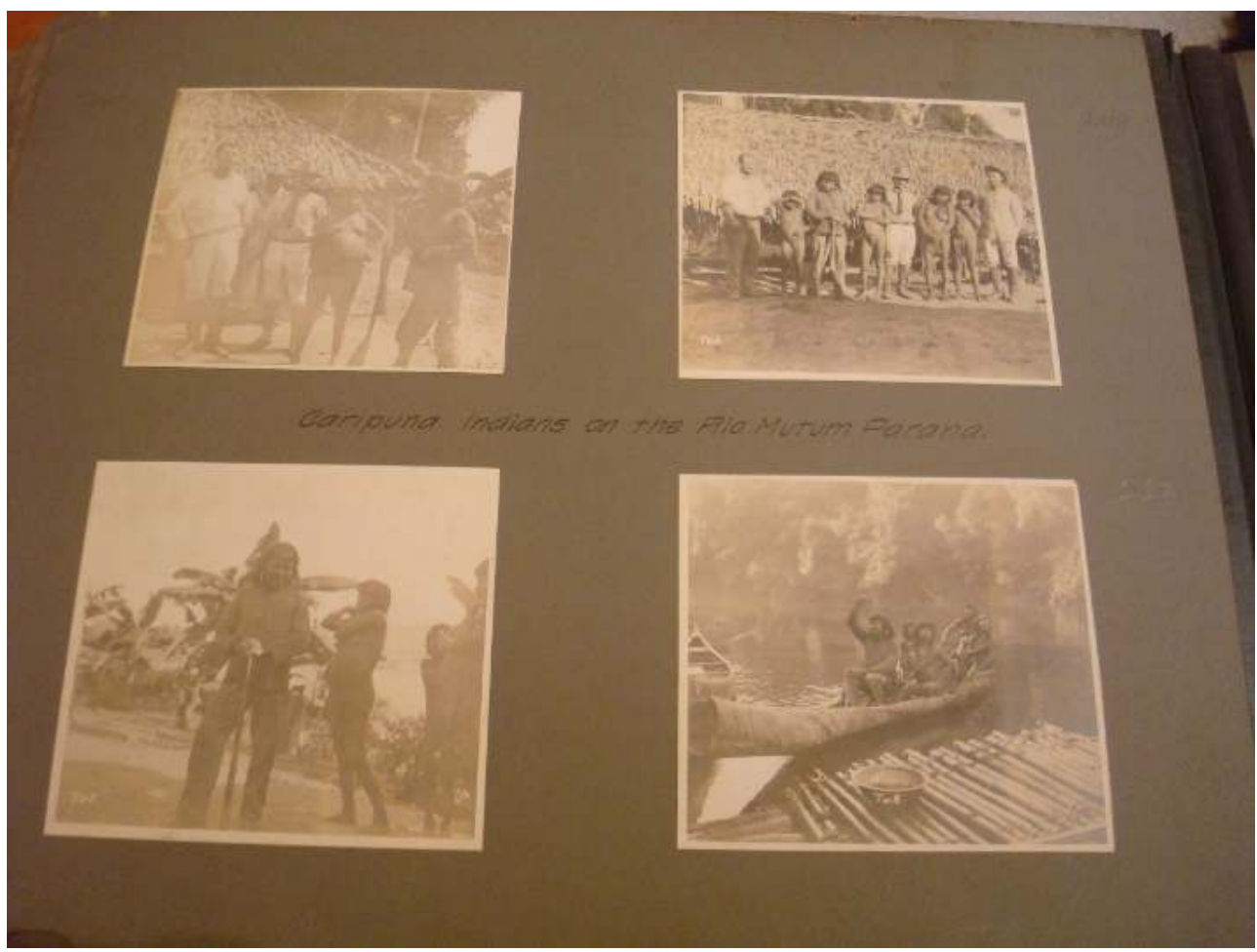

Figure 3: Dana Merrill's album at the NYPL.

6 Merrill's colleagues' articles and books join a long bibliography on the Madeira and Mamoré Valley. The earliest among these texts is a 1723 report written by an anonymous member of a military expedition to the Madeira and Mamoré Rivers led by Portuguese explorer Francisco de Melo Palheta (ANONYMOUS 2004). In 1790, Portuguese army 
engineer Ricardo Franco d'Almeida Serra wrote about his visit to the area in 1782. In 1854, American explorer Lardner Gibbon published his observations made during his expedition to the Valley in the 1850s. George E. Church, an American engineer and geographer who led a failed attempt to build the MMR in 1872, published a volume collecting his and other reports in 1875. In the same year, German engineer, artist, and explorer Franz Keller-Leuzinger, responsible for the first study on the feasibility of the MMR, wrote about the Valley in a book richly illustrated with his impressive woodcuts.

7 Writers have identified native groups living in the Madeira and Mamoré Valley as Mojos, Parintintins and, less frequently, Araras, Mutum, and even Arawak (BAYLISS 1928). ${ }^{6}$ These authors were not always ethnologists; moreover, many local tribes virtually disappeared prior to formal ethnological descriptions were completed, so their identification is not entirely reliable. In any case, the indigenous group closest to the area where the MMR was built has traditionally been identified as Karipuna (also "Caripuna), a group usually perceived as friendly or at least approachable. ${ }^{7}$ Serra (1790: n.p.) thought they were "completely savage" and "suspicious," but not dangerous. Gibbon (1854: 295) wrote that the Karipuna were "extremely obliging," and Church stated that they were "inoffensive, easily managed" and "aided rather than obstructed progress in that direction" (1875: 37). Not all authors shared the same impression, however. KellerLeuzinger (1875: 62) felt "forced to modify the good impression" he had of the Karipuna after learning of their attack to an expedition eight years prior to his visit.

\section{Markers of Typicality}

8 Unlike the German, Merrill's colleagues looked forward to opportunities to meet the Karipuna. In one of the few clues we have to guidelines given to the photographer, Kravigny (1940:124) tells that the MMR chief engineer was "very anxious" for pictures of the indigenous population. In order to get his photographs, Merrill (KRAVIGNY 1940: 124) gifted the Karipuna chief some pajamas, which the chief "donned at once," and perhaps the 768 picture was taken on that occasion. The photographer often gave his sitters clothes, mirrors, brushes, and coins in exchange for pictures and indigenous artifacts. His "lavish" gifting even prompted other workers to warn him that he would "spoil the market" as the Karipuna could become more demanding (KRAVIGNY 1940: 125). Merrill's engagement in barter demonstrates that his photographs were the result of an active effort to capture the natives' likeness to fulfill his and his colleagues' wishes. In The Jungle Route, Kravigny (1940: 117; figure 4) captioned a photograph of a Karipuna man stringing a bow as a "surprise shot," something unlikely considering the proximity of the photographer to his subject. In fact, knowledge of Merrill's transactions dissipates any impression that he had caught his subjects unaware in fortuitous encounters and, indeed, on the next paragraph Kravigny contradicts himself by explaining that the photograph was the return for a suit of pajamas given by Merrill. 


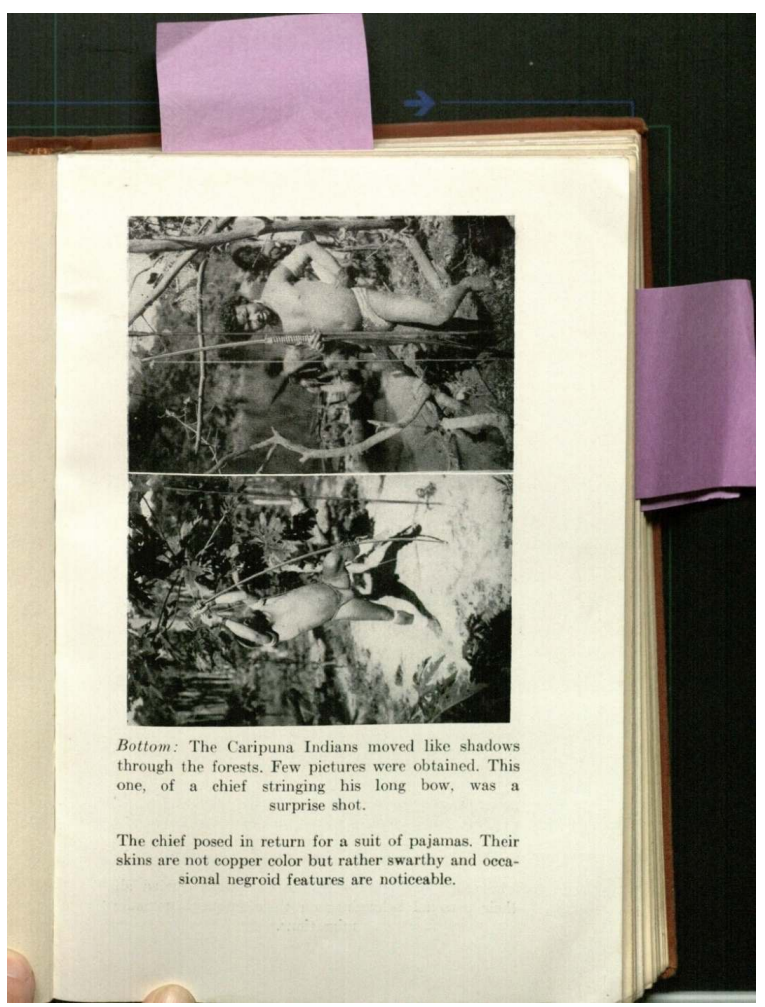

Figure 4: Photograph by Dana Merrill, reproduced in Kravigny's book The Jungle Route (1940: 117).

9 The people living in and around the MMR complex participated in an economy in which objects functioned as tokens in exchanges entwined with the making of images of indigeneity. Amerindians looked after industrialized objects and Americans were interested in exotic "curios" and the natives' semblance. Such phenomenon was not unique to the MMR complex. Earl Parker Hanson, an American explorer who visited Rondônia in the 1930s, tells an anecdote that illustrates the negotiations of material culture and images that plays into a semiotics of indigenous "purity" to cater to westerners' expectations. During his visit, Hanson (1938: 752) wanted to photograph a Brazilian native with a blowgun, but his indigenous subjects wore western clothes. Worried that a fully-clothed man would look to the American audience as a "fake Indian," he gave his sitter a flask of gunpowder in exchange for him to pose naked, concluding that the photograph had to be staged to be accepted "as genuine" in the United States. Pictures such as the one of the Karipuna holding a bow and arrow reproduced in Kravigny's book were especially valued because they conformed to old stereotypes of indigeneity.

Besides the bow and arrow, spear, and blowgun, the bark canoe, as the one in photograph 768, was another object that repeatedly appeared in visual and textual representations of the Madeira and Mamoré Valley. Merrill emphasized the canoe in the photograph reproduced in Ashmead's text (figure 2), an image that again shows his attention to composition. The crooked diagonal of the river margin and the horizontal line where the river meets the forest divide the vertical surface into three parts. An empty canoe lies on the river bank, conspicuously in the first plane. In the mid-left, cropped by the frame, we see part of a wicker basket or similar artifact. Ashmead (1911: 437) captioned the photograph "peculiar type of canoe used by the Caripuna Indians on the Mutumparana," highlighting the object. 
11 anonymous member of the Mello Palheta's expedition (1960: 158) observed that the Karipuna came from the river on a "wooden bark" (casca de pau) to meet them. Gibbon (1854: 287) gives a thorough delineation of the natives' canoe, "constructed of one piece of bark, twenty feet long, and four feet beam," and so on. Keller-Leuzinger (1875: xvi) is similarly careful in his description of the bark canoe, bows and arrows, and other artifacts such as baskets. One example of his admiration for native craftsmanship is the statement that there could be "no lighter, simpler, and better-constructed crafts in the world" than the bark-canoes of the Karipunas and Araras.

er aspect of indigenous life that caught Americans' attention was nakedness, an aspect that has fascinated the western visitor since the first arrival of Europeans. Like bows and arrows and the canoe, the lack of coverage marked the exoticism of Ameridians. It also exposed the Karipuna body to the scrutiny of MMR workers who came to conclusions about indigenous habits after visual examination of the natives (BAYLISS 1928:200; KRAVIGNY 1940: 25). Kravigny (1940: 123), for example, reported that the natives were "mostly of plump figures" and paid particular attention to "their distended abdomens," a condition that he interpreted as a result of "their starchy diets and alternate feasts and famines." Merrill's photographs (figures 5 and 6) often placed the Karipuna side-by-side, on display for the camera. They often pose besides or in front of tall American men, a visual strategy commonly used at the time to demonstrate the supposed superiority of the white body (BEDERMAN 1995: 21).

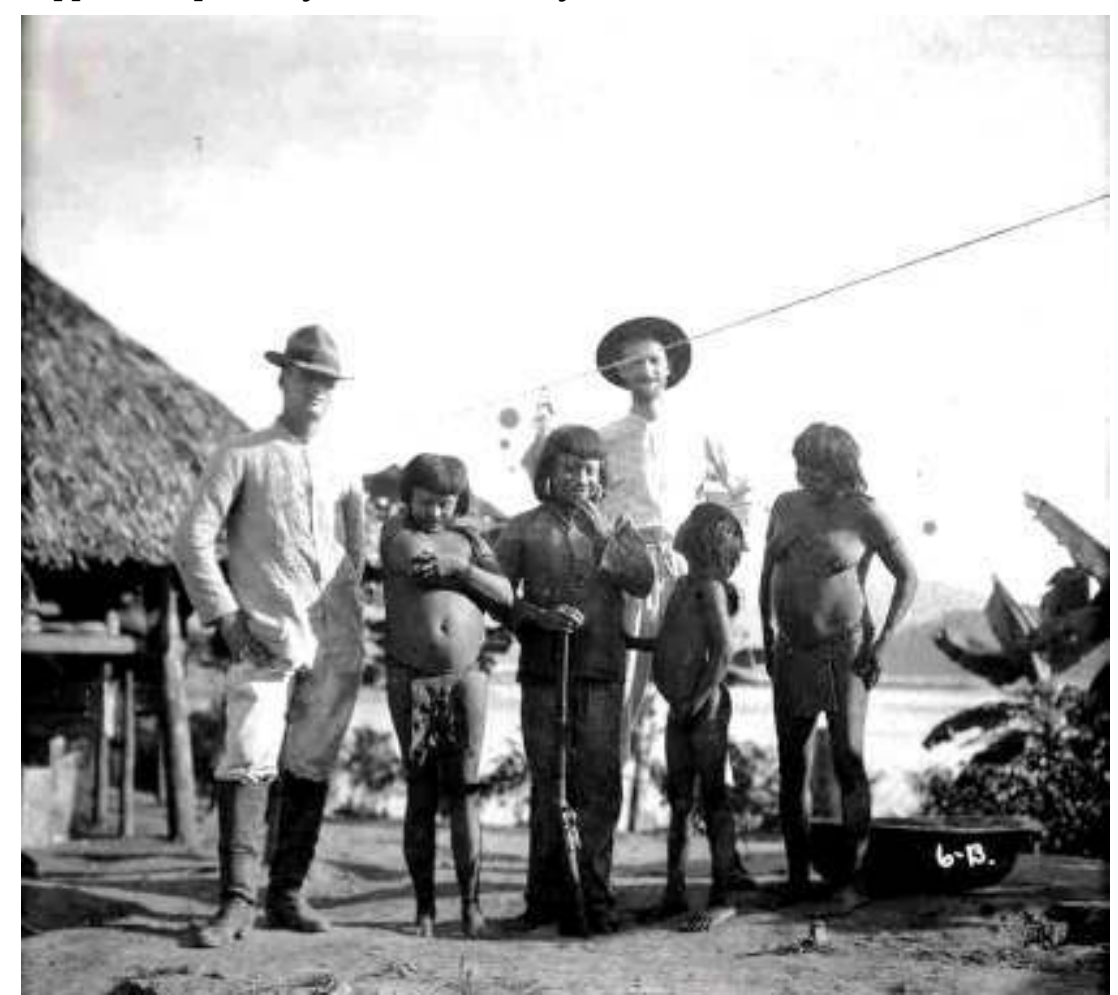

Figure 5: Photograph by Dana Merrill, 1909-1911. Glass negative (Museu Paulista). 


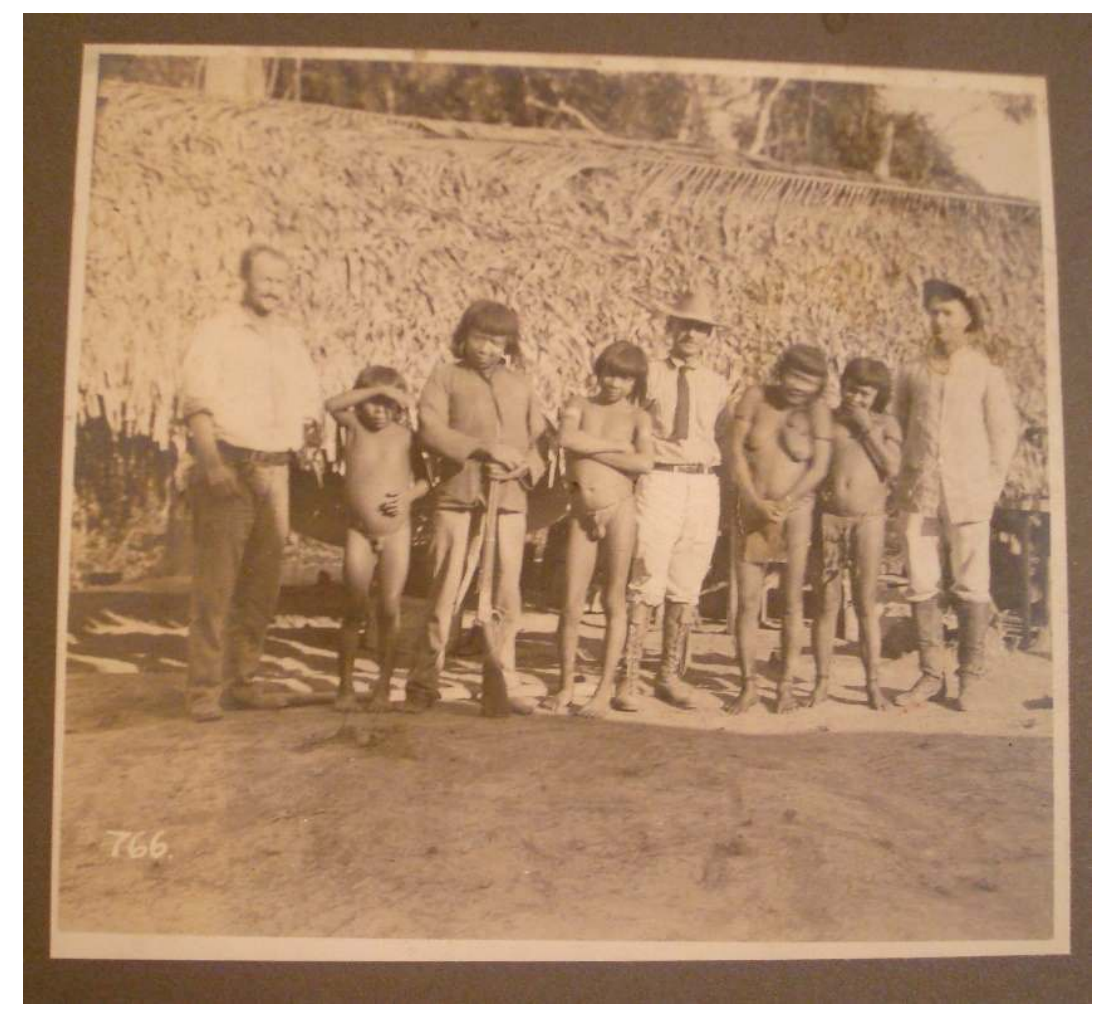

Figure 6: Photograph by Dana Merrill, 1909-1911. Gelatin silver print (NYPL).

Nakedness, the bark canoe, and the bow and arrow were markers of typicality that signaled "pure" indigeneity in representations attuned to the trope of the Noble Savage, an idealized Other who lives in harmonious unity with a bountiful nature. Even though he was not fond of the Karipuna, Keller-Leuzinger was the author who most prominently depicted them as Noble Savages. In his woodcuts, like other Amazonian dwellers, the Karipuna were strong, classically-proportioned men and women who looked poised even under strenuous effort, and lived in harmony with an edenic, marvelous forest (figure 7 and 8). In Keller-Leuzinger's renderings of the Madeira and Mamoré Valley population the Karipuna are "pure," untouched natives, and there are no elements suggesting any kind of contact between westerners and the Karipuna, who are naked or wear loincloths, carry bows and arrows, and travel on canoes (figure 7, 8, and 9). Keller-Leuzinger's decision to depict the indigenous group in such a positive way makes sense, first because the German's goal with the book was to convince his countrymen to migrate to the tropical forest. Second, his expedition was financed by the Emperor Dom Pedro II, a major proponent of Brazil's own strain of indigenism, indianismo. ${ }^{8}$ Similarly to other Latin American versions, in Brazil the nineteenth-century romantic movement sought in the image of the pure Indian a nationalist symbol distinctive from European metropolises (although, of course, Dom Pedro was still the son of the Portuguese king). 


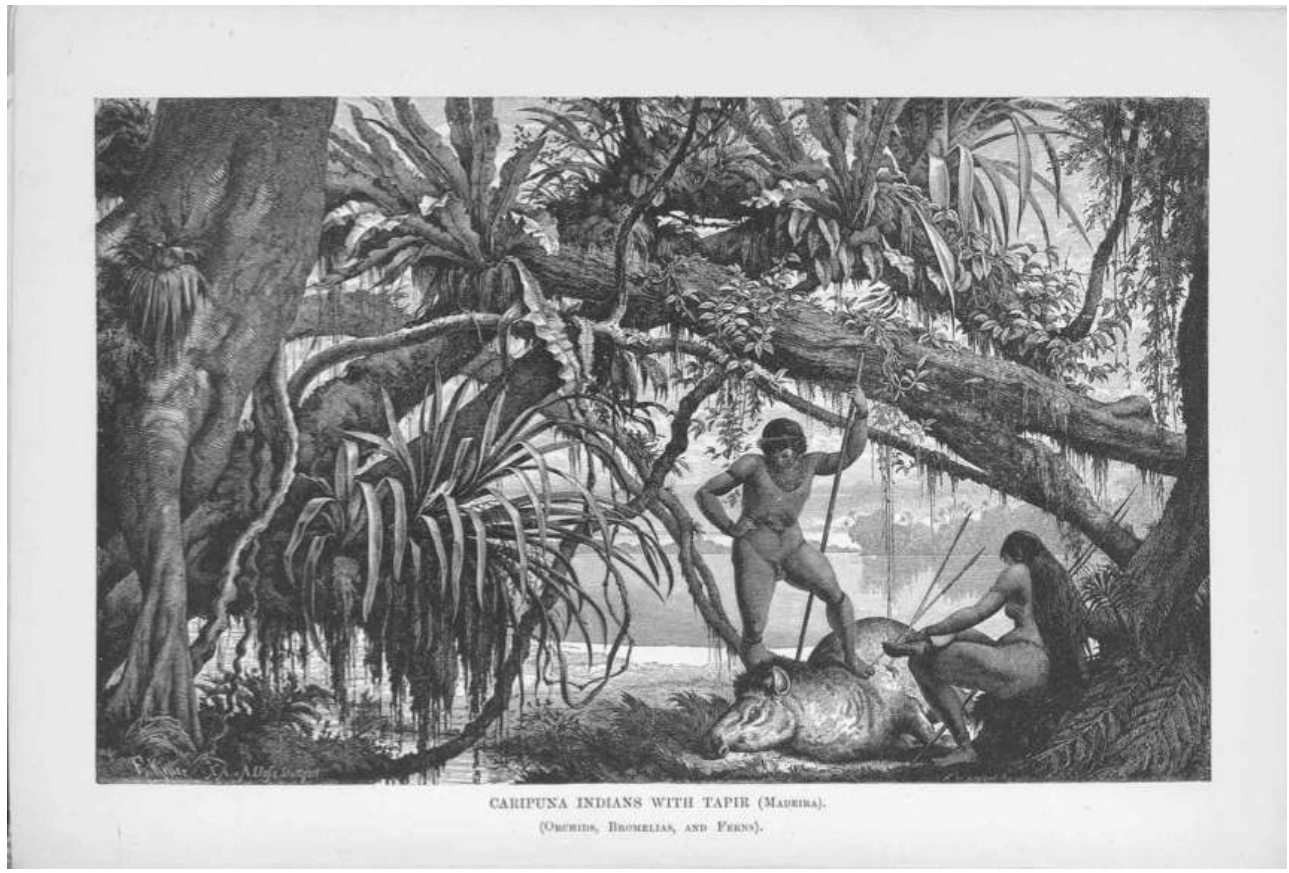

Figure 7: "Caripuna Indians with Tapir (Madeira)." Woodcut by Keller-Leuzinger (1875: 105).

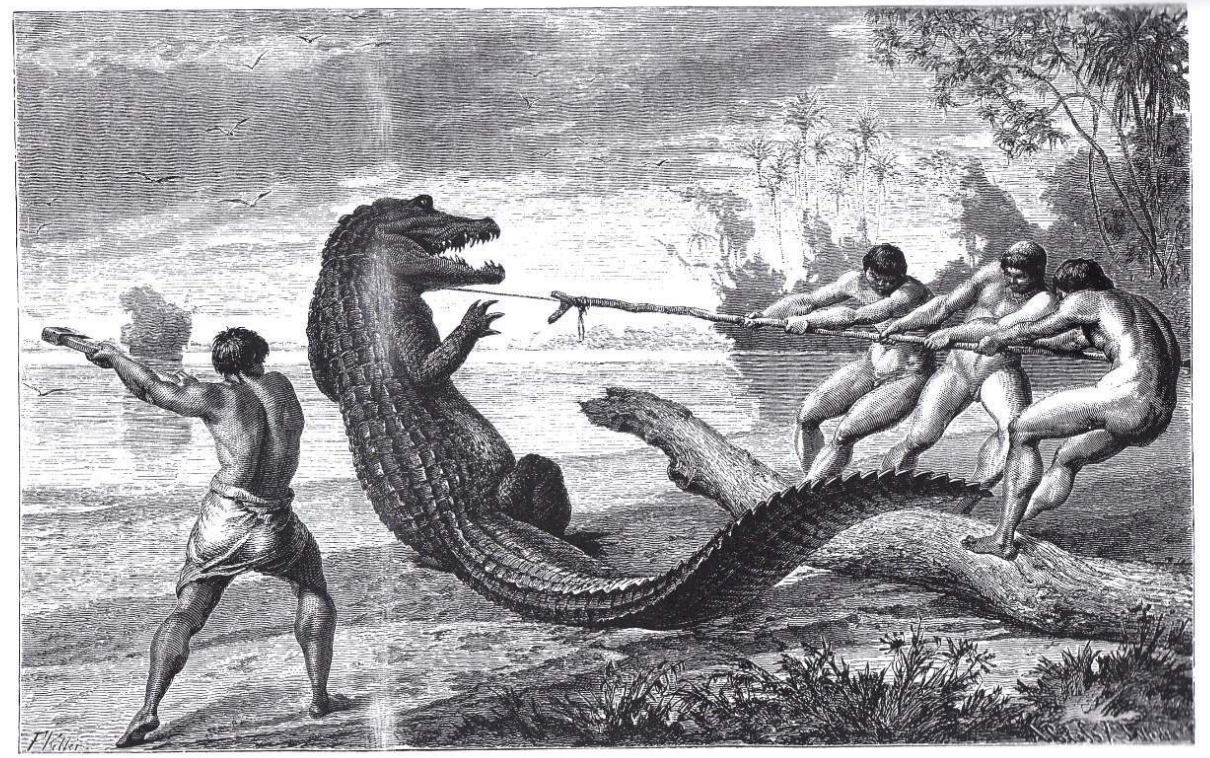

Figure 8: "Catching an Alligator with Lasso (Madeira)." Woodcut by Keller-Leuzinger (1875: 90). 


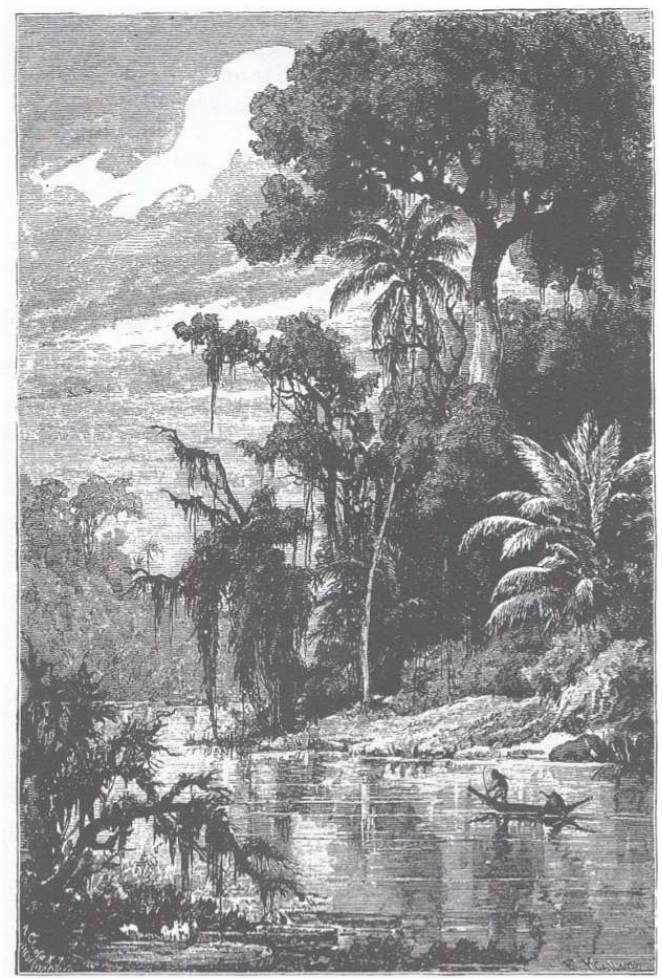

Figure 9: "Mouth of a Lateral River on the Madeira, with an Indian Shooting Fish." Woodcut by KellerLeuzinger (1875: 126).

14 Nudity, arrows, and a canoe also feature in Gibbon's depiction of Matuá and Manú, Karipuna brothers he met near the Madeira rapids (figure 10$).{ }^{9}$ One of them looks older than the other, but both have equally bloated stomachs. They stand ashore in front of a quiet river and a swatch of nondescript vegetation. A bark canoe is tied to a row stuck into the river bank. The oldest brother wears necklaces and carries an arrow placed in front of his genitalia, resulting in an awkward phallic effect. For Susanna Hecht (2013: 150), Gibbon depicted Amerindians as Noble Savages, and indeed in writing he was more tolerant then Keller-Leuzinger of the Karipuna. Gibbon's lithograph, however, gives a different impression as his Karipunas' swollen bellies and bizarre spear make them a far cry from any ideal. Moreover, an element placed between the child and the canoe - a monkey mounting on a dog held by the boy - disturbs the stillness of the picture, and brings to mind allusions to the exotic Animalia and unorthodox breeding often associated with Brazil. 


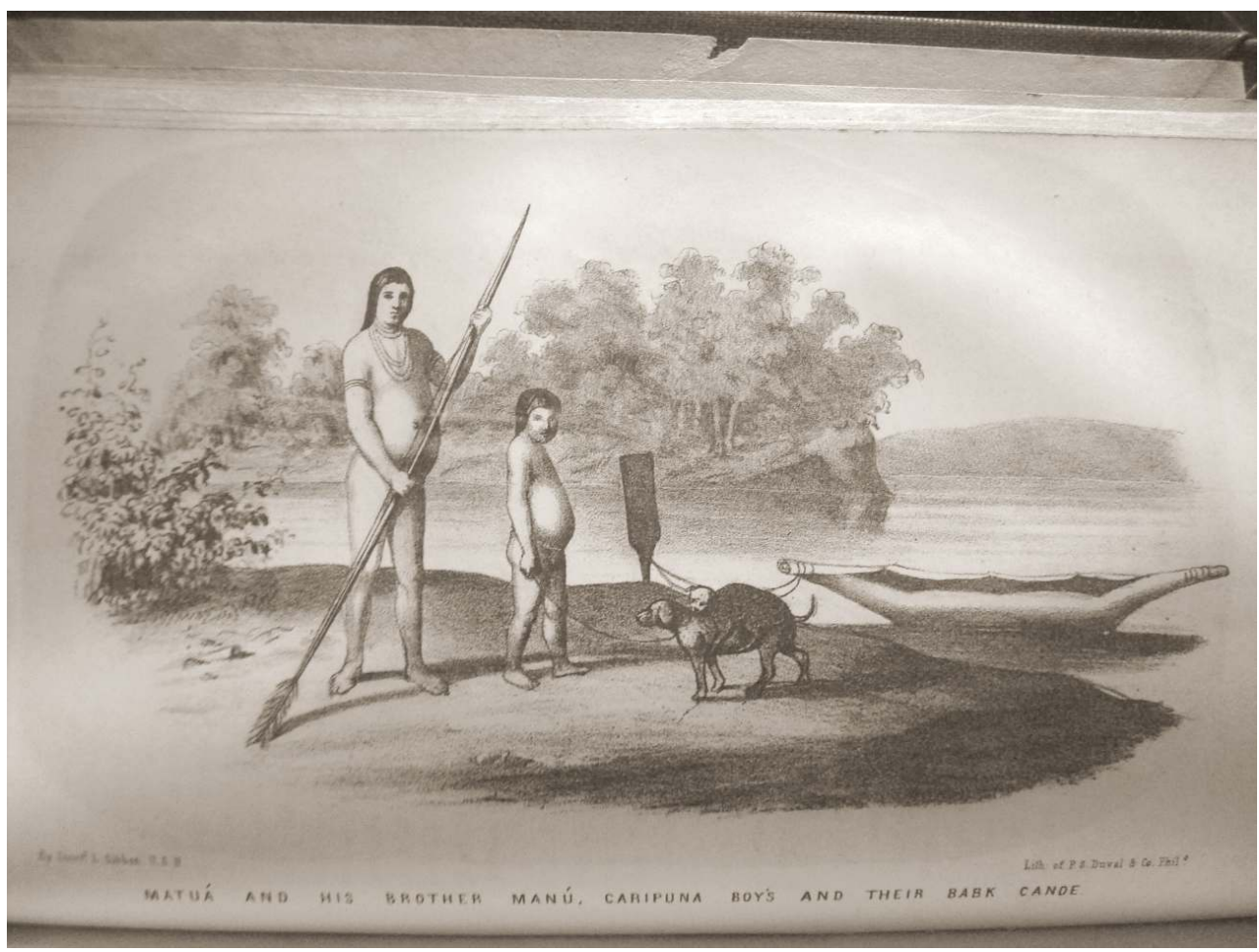

Figure 10: "Matuá and his Brother Manú, Caripuna Boys and their Bark Canoe." Lithograph by Gibbon (1854: insert between pages 294 and 295).

\section{The Noble Savage and the Vanishing Race}

In Brazil, Indianismo was so strongly connected to the Emperor that the trope lost force after the proclamation of the republic in 1889. Around the same time, idealized images of indigeneity were again circulating in American culture, where they served a distinctive narrative. If early in the nineteenth century the longstanding trope of the Noble Savage had lost impetus in the United States, towards the end of the century the figure reemerged with a new force, incarnated in the ideology of the Vanishing Race. According to this mindset, the image and memory of native cultures should be preserved, as Amerindians were expected to disappear due to their inability to adapt to the changes brought by white civilization. The Vanishing Race myth resonated with at least some MMR employees. Bayliss (1928: 200), for example, thought it was safe to say that, if the Madeira Valley was ever to be "appropriated for the ways of civilization," native Amazonians would "vanish," as a result of the "survival of the fittest," that is, the white race. The construction of the MMR coincided with the beginning of the most emblematic visual rendition of the Vanishing Race, the project of ethnologist Edward S. Curtis (1868-1952) to document native North American groups. For almost three decades, Curtis created more than forty thousand photographs of over eighty tribes. He also registered indigenous languages and music in wax cylinders, produced films, and wrote accounts of their social structures, cultural practices, and beliefs. Curtis's project was scientific in its intent to fully document and describe the Other, but his soft-focused sepia photographs conformed to the pictorialist aesthetics that circulated in art galleries. They depict men and women in traditional clothing, riding horses and canoeing in pristine scenery, and indigenous objects. 

timeless and unchangeable. In Roosevelt's foreword to the first of Curtis's twenty-volume The North American Indian, the President argued that it was important to preserve a record of indigenous ways of life that were "passing away," and praised the photographer's ability to portray the integrity of American Indians (ROOSEVELT 1907, 1: ix). Roosevelt's words demonstrate that the Vanishing Race's commitment to preserve "pure" indigeneity did not extend to a concern with the well-being of living aboriginal people. From the Anglo-American perspective, the only chance Amerindians had to survive was through assimilation, but paradoxically, "impure" Indians were not worthy of respect. To maintain the "authenticity" of his sitters, Curtis eliminated references to western presence from his images. As Pinney (2011: 92-3) observed, when a photograph of two men in ornate traditional dress was reproduced in The North American Indian as a photogravure, Curtis removed an industrialized metal object (a clock or a medal) from the scene.

One photograph by Merrill demonstrates a similar a strategy of erasing white presence among natives, quite literally. Numbered 427 (figure 11), it depicts four indigenous men (one might be a woman; it is hard to tell from the image) standing on the river bank. They just got off a bark canoe loaded with bows, arrows, and other artifacts. Three of them do not wear western clothes, only waistbands and armbands; the other one wears pants. They all face the camera. Tree trunks and branches in the foreground form a triangle that frames the group, superimposed on the smooth surface of the river on the background. Among the Karipuna there is a white man wearing a light-colored shirt and a hat. In a print in the NYPL album, Merrill scribbled over the man with a pencil (figure 12). The same photograph was reproduced in Bayliss's testimony with the caption "The Arawaks Have their Bows and Arrows in the Canoe" (1928: 194), placed right below picture 768 as if implying that the "Arawaks" in the first image had just arrived at their destination, even though these are clearly not the same people. Although in this reproduction the white man does appear, his image looks "burned" so that he blends with the background. The photograph appeared again in Kravigny's book without any evident intervention, but in the grainy reproduction, the image of the man blends with the background, making him hard to devise (figure 13). We can only guess what prompted Merrill to erase the white man from the picture. What is evident is that the sitter is comfortable among the Karipuna. His casual presence among the natives suggests a degree of interaction between Ameridians and whites that would contradicts the stereotype of isolated indigene set forth by the Vanishing Race ideal. 


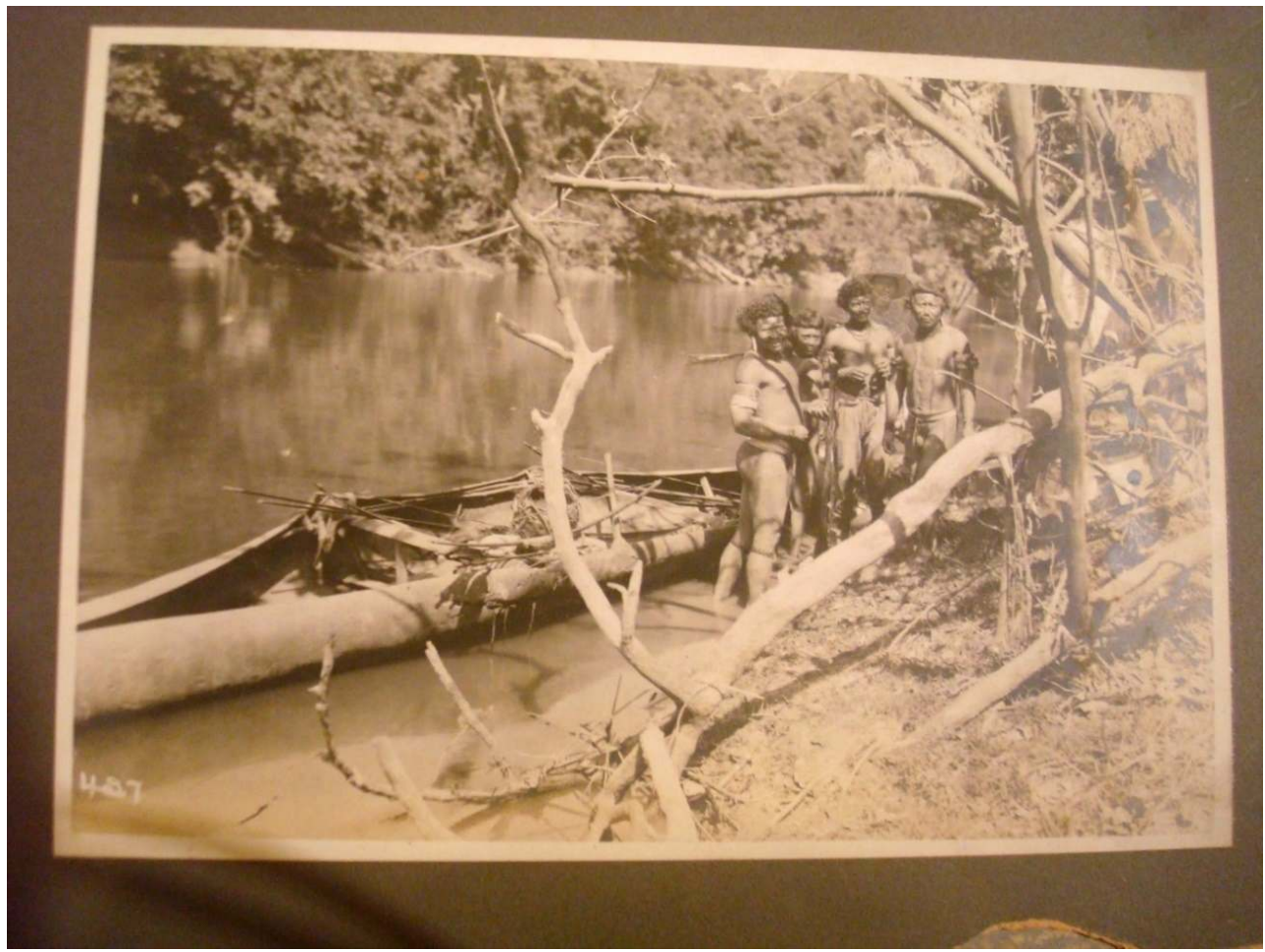

Figure 11: Photograph 427 by Dana Merrill, 1909-1911. Gelatin silver print (NYPL).

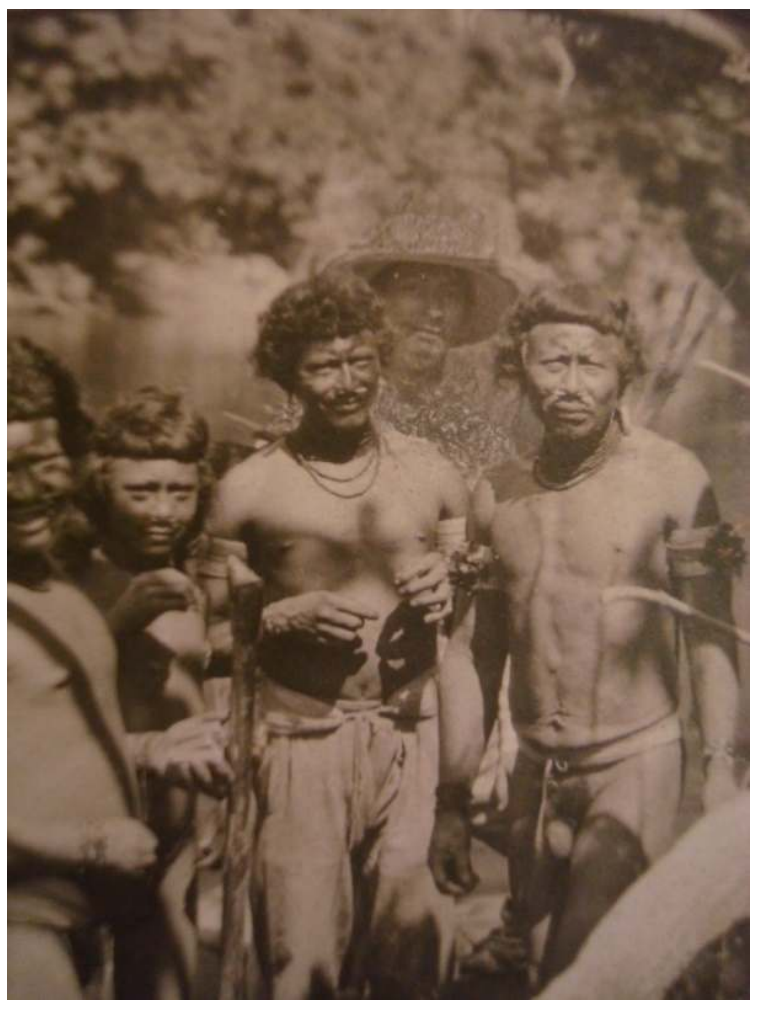

Figure 12: Detail of previous image. 


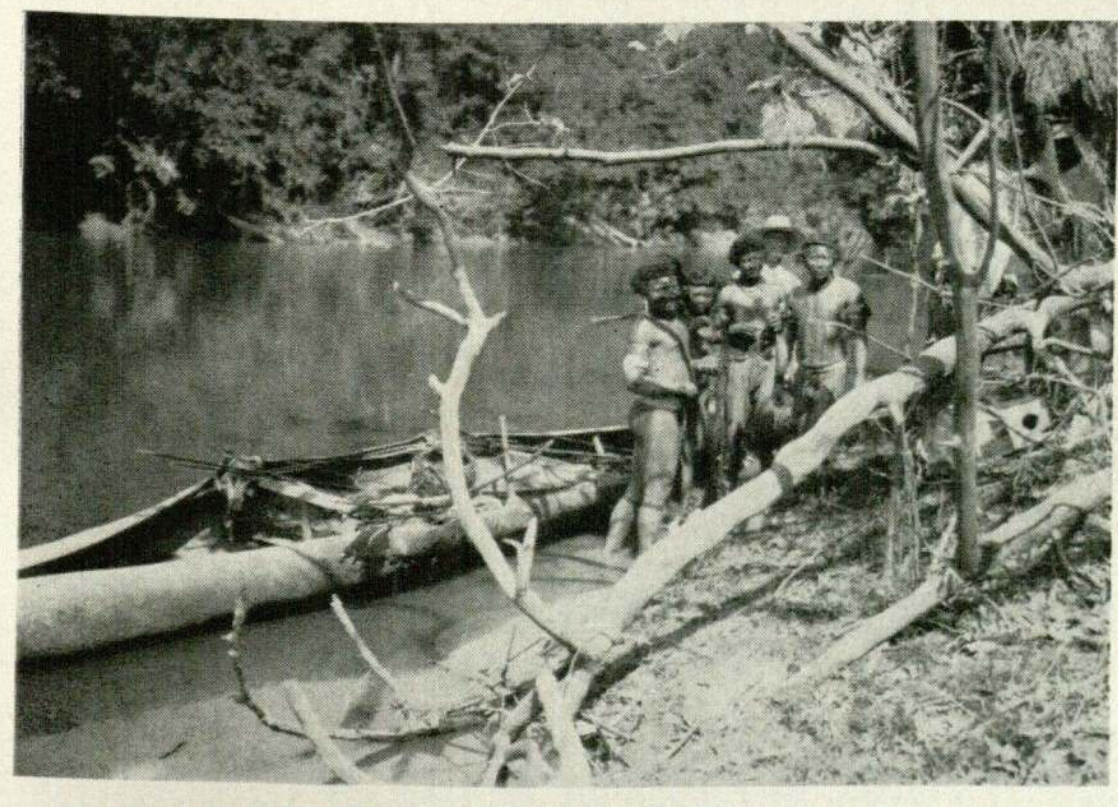

Figure 13: Photograph 427, as reproduced in Kravigny's book (1940: 119)

This kind of manipulation, as well as Hanson's and Merrill's posing negotiations with sitters, demonstrate how natives can function as "a semiotic pawn on a chess board" controlled by "the white signmaker," to borrow Terry Goldie's words (1989: 10). On the same vein, Susan Sontag (2005: 50) argued that nineteenth-century photographs of native North Americans were the "most brutal" case of "colonization through photography." But we should be careful when assigning absolute control over images to their producers, especially when we are dealing with photographs. As Pinney (2003) noted, although photographers do manipulate pictures, they have no complete command over everything that appears in the final image. The author reminds us that the camera lens is unable to discriminate and therefore it always allows for "a substrate or margin of excess" (PINNEY 2003: 7). Photography's indexicality thus does not imply fixity, but rather lets the unexpected to "leak out" to the surface. Leakage or lack of control is evident not only in the picture surface but also in the disconnection between images and texts, for example in Bayliss's use of the 768 photograph to illustrate an account that emphasized the Karipuna's isolation. Even though it was reproduced in a text centered on the trope of untouched indigeneity, 768 shows a hybrid reality: the pajamas, the metal bowl, and the dog are elements that signal the natives' contact with whites.

This type of disconnection can happen even in images and texts created by the same person, as in Gibbon's case. The dog in his lithograph is a clear evidence of the contact between Amerindians and whites. Curiously, domestic dogs appear in one of the earliest representations of Brazilian indigeneity, the 1641 painting of a Tapuya Woman (figure 14) by Dutch artist Albert Eckhout (ca. 1610 - ca .1666). Among Eckhout's eight portraits of Brazilian couples, the Tapuya were the most primitive, associated with uncultivated forests, nakedness, and anthropophagy. Yet domestic dogs were not originally found in Brazil; rather they are animals imported by Europeans. ${ }^{10}$ The dog demonstrates the penetration of western products into indigenous society, a process that was already underway by the time of Gibbon's visit to the Karipuna. In fact, Europeans and LusoBrazilians had been in the Madeira and Mamoré Valley since the seventeenth century to 
trade drogas do sertão; the Príncipe da Beira Fortress was built in Rondônia in 1770; and Jesuit missionaries founded the aldeia Tupinambarana on the right margin of the Madeira during the last quarter of the eighteenth century.

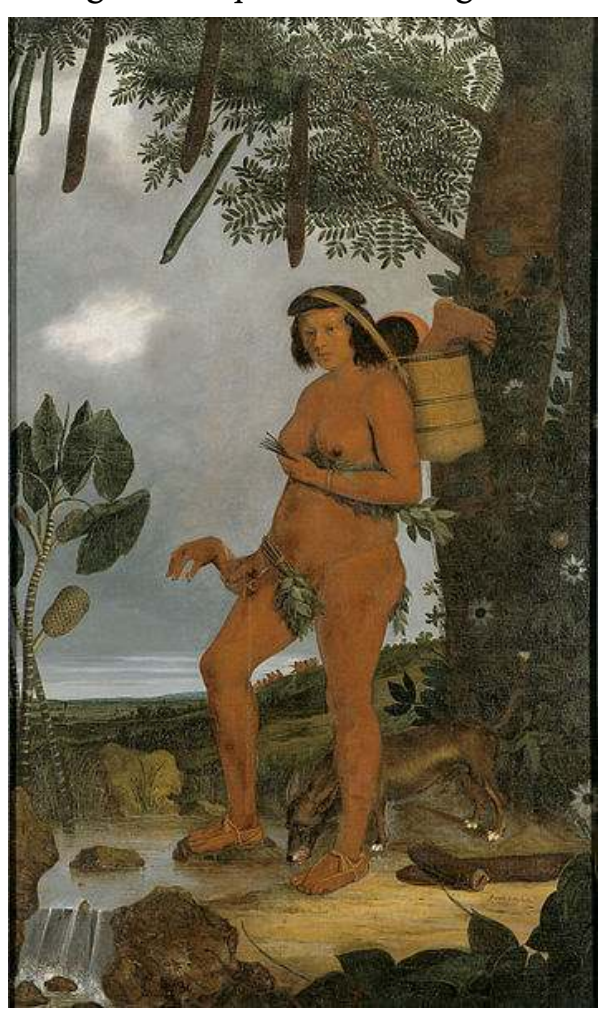

Figure 14: Albert Eckhout, Tapuya Woman, 1641. Oil on canvas. National Museum of Denmark.

As a matter of fact, in spite of the later interference in photograph 427, while in Brazil Merrill registered elements that signaled the natives' appropriation of western objects. His gaze was directed as much to bark canoes and bows and arrows as to industrialized objects. This is evident in photograph 768 , where he clearly chose to include the metal bowl in the foreground. What comes through in Merrill's depictions of Amazonians is a lack of commitment to the tropes of indigenous purity. As a corporate photographer working with relative freedom away from the Company's headquarters, Merrill was not constrained to registering only "pure" indigeneity. Rather, he adapted visual vocabularies to his needs, combining "pure" and "impure" elements in photographs that often depict the Karipuna wearing western clothes and carrying firearms. Thus, although his gaze was (also) attracted to markers of typicality, Merrill did not depict the Karipuna as idealized Noble Savages. Without the scientific and romantic gravity that informed a project such as Curtis's, Merrill's views of Amerindians were more pliable. As the photographer left no written document, comments by his colleagues might offer clues to his thinking on the natives. One example is a poem titled "In Far-Away Bolivia" signed by "R. S. S." and published in 1909 in The Porto Velho Weekly Times, the newspaper edited in Rondônia by MMR American employees. It jokingly sums up MMR men perceptions of Amazonian natives: "There the Indian often roves, attired in everything - but clothes, with his spear and poisoned arrow, often dines on human marrow." 11 The poem brings together the markers of typicality that structured the stereotype of the "pure Indian" the canoe, the arrow, nakedness, and anthropophagy - but without alluding to an idealized indigeneity. For Goldie (1989: 234), representations of indigeneity are informed 
by two poles of attraction: one pole being the fear of the "demonic violence of the fiendish warrior," the other pole, the desire for the "dusky maiden." MMR workers, however, downplayed both of these extremes. The stereotype was neither romantic nor fearful, mocking even the most distinctive marker of indigenous difference, anthropophagy.

Now I want to return to photograph 768 to discuss what I believe is the most revealing element of hybridity in the photograph, the gesture of the Karipuna man. Kravigny (1940: 139) described the image as "Caripunas pose for a farewell picture, the chief wearing his new clothes. A balsa wood raft in the foreground." He does not explain why he used the italicized word "pose," but he was likely referring to the gesture of the man who places his hands on the shoulder. Kravigny was probably just ridiculing the Karipuna as primitives who could not understand the mechanics of posing, but the indigenous man seems deliberate in his attitude. He must have witnessed white men posing as Merrill took several portraits of his American colleagues near the natives. More than demonstrating Amerindian mindless incorporation of exogenous practices, the photograph calls into question who is mocking whom in this encounter. It challenges Goldie's and Sontag's deterministic interpretations by presenting the indigenous sitter not only as a passive "pawn" of the white gaze, but as a subject with his own perspective on picture taking.

\section{Coda}

By suggesting Amerindians' participation in their interactions with Americans I do not mean that the two groups were on equal terms. There are no detailed records of what happened to the Karipuna in the Madeira Valley, but besides the disruption of game and fishing as well as direct attacks by whites, we know that western clothes and objects have propagated diseases among native societies since the arrival of Europeans. The destruction of the Karipuna was mostly complete by the time the MMR started to operate. One of Merrill's photograph of the Karipuna man holding a bow and arrow reproduced in Kravigny's book was turned into a postcard. ${ }^{12}$ Sent in 1914 by Engineer George Hepburn to his father, who had participated in the earlier attempt to build the railroad in 1872, it asks: "Dear Father:- Does this specimen of South American Indians look familiar to you? They say here that the Karipuns [sic] are mostly exterminated. Only about 60 left."

\section{BIBLIOGRAPHY}

ANONYMOUS. "A bandeira de Francisco de Melo Palhêta ao Madeira e o documento de narração da viagem." In Caminhos antigos e povoamento do Brasil, edited by J. Capistrano de Abreu, 141-59. Recife: Edições Demócrito Rocha, 2004.

ASHMEAD, P. H. "The Madeira-Mamoré Railway." Bulletin of the Pan-American Union 32 (March 1911): 432-52. 
BEDERMAN, Gail. Manliness and Civilization: A Cultural History of Gender and Race in the United States, 1880-1917. Chicago and London: The University of Chicago Press, 1995.

BAYLISS, John J. "Recollections of an Engineer in Brazil." Stone and Webster 43 (August 1928): 180-201.

BROWN, Elspeth H. The Corporate Eye: Photography and the Rationalization of American Commercial Culture. Baltimore: The Johns Hopkins University Press, 2005.

CHURCH, George Earl. The National Bolivian Navigation Company. New York: [John W. Amerman, Printer], n.d.

COLEMAN, Kevin. A Camera in the Garden of Eden: The Self-forging of a Banana Republic. Austin: University of Texas Press, 2016.

FERREIRA, Manoel Rodrigues. A ferrovia do Diabo. São Paulo: Melhoramentos, 2005.

GIBBON, Lardner, Lt. Exploration of the Valley of the Amazon. Part II. Washington: A. O. P. Nicholson, Public Printer, 1854.

GOLDIE, Terry. From Fear and Temptation: The Image of the Indigene in Canadian, Australian and New Zealand Literatures. London, Montreal, and Buffalo: McGill-Queens University Press, 1989.

HANSON, Earl Parker. Journey to Manaos. New York: Reynal \& Hitchcock, 1938.

HECHT, Susanna B. The Scramble for the Amazon and the Lost Paradise of Euclides da Cunha. Chicago: University of Chicago Press, 2013.

KELLER-LEUZINGER, Franz. The Amazon and Madeira Rivers: Sketches and Descriptions from the NoteBook of an Explorer. 2nd ed. Philadelphia: J. B. Lippincott and Co., 1875.

KRAVIGNY, Frank. The Jungle Route. New York: Orlin Tremaine Company, 1940.

LOME, Herbert M. “An American Sanitary Triumph in Brazil.” World's Work 20 (May 1910): 12951-56.

MALDI, Denise. "O complexo cultural do Marico: sociedades indígenas do Rio Branco, Colorado e Mequéns." Boletim do Museu Paraense Emílio Goeldi 7, no. 2 (1991): 209-69.

MARCHAND, Roland. Advertising the American Dream: Making Way for Modernity, 1920-1940. Berkeley: University of California Press, 1985.

MARCHAND, Roland. Creating the Corporate Soul: The Rise of Public Relations and Corporate Imagery in American Big Business. Los Angeles and Berkeley: University of California Press, 1998.

MASON, Peter. "On Producing the (American) Exotic." Anthropos 91, no. 1./3. (1996): 139-51.

MCCULLOUGH, David G. The Path between the Seas: The Creation of the Panama Canal, 1870-1914. New York, NY: Simon and Schuster, 1977.

MERRILL, Dana B., and Groesback Walsh. Views of the Estrada de Ferro Madeira e Mamoré, Amazonas \& Matto Grosso, Brazil S.A. [1939]. MFZ+++ (Merrill) 81-795. Photography Collection. New York Public Library, New York.

NYE, David. Image Worlds: Corporate Identities at General Electric, 1890-1930. Cambridge, Mass., and London: The MIT Press, 1985.

PINNEY, Christopher. Camera Indica: The Social Life of Indian Photographs. Chicago: The University of Chicago Press, 1997.

PINNEY, Christopher. Introduction to Photography's Other Histories, edited by Christopher Pinney and Nicolas Petersen, 1-14. Durham and London: Duke University Press, 2003. 
PINNEY, Christopher. Photography and Anthropology. London: Reaktion Books, 2011.

POOLE, Deborah. Vision, Race, and Modernity: A Visual Economy of the Andean World. Princeton: Princeton University Press, 1997.

ROOSEVELT, Theodore. Foreword to The North American Indian, by Edward Sheriff Curtis, xi. Vol. 1. Cambridge: Cambridge University Press, 1907.

SEKULA, "Dismantling Modernism: Reinventing Documentary (Notes on the Politics of Representation).” The Massachusetts Review 19, no. 4 (Winter 1978): 859-83.

SCHWARCZ, Lilia Moritz. The Emperor's Beard: Dom Pedro II and the Tropical Monarchy of Brazil. Translated by John Gledson. New York: Hill and Wang, 2004.

SERRA, Ricardo Franco d'Almeida. "Novo diário de viagens dos Rios Madeira, Mamoré e Guaporé, até Villa Bella, capital do Governo de Matto Grosso." 1790. Biblioteca Nacional, Rio de Janeiro.

SONTAG, Susan. On Photography. New York: RosettaBooks in arrangement with Farrar, Straus \& Giroux, 2005.

VELDEN, Felipe Ferreira Vander. "Sobre cães e índios: domesticidade, classificação zoológica e relação humano-animal entre os Karitiana." Avá, no. 15 (December 2009). Accessed October 17, 2016. http://www.scielo.org.ar/scielo.php?script=sci_arttext\&pid=S1851-16942009000200006.

ZIMBALIST, Andrew, and John Weeks. Panama at the Crossroads: Economic Development and Political Change in the Twentieth Century. Berkeley: University of California Press, 1987.

\section{NOTES}

1. Photographic prints are housed at the J. Marriott Library, at the University of Utah, and at the Institute for Historical and Artistic Heritage (IPHAN) of Rondônia, Brazil.

2. In his analysis of the MMR death toll, Brazilian historian Manoel Rodrigues Ferreira (2005) estimated that a relatively reliable death toll for the construction period stood around 6,200 in a total workforce of about 30,000, meaning that approximately one-fifth or twenty percent of workers died during the construction of the line (FERREIRA 2005: 302). As a comparison, the official death toll for the Panama Canal construction between 1905 and 1914 is 5,609, although here again the actual number is certainly higher, and might have even reached 15,000 (MCCULLOUGH 1977: 173). The average annual workforce on the Canal, however, was roughly 42,600, much higher than the MMR (ZIMBALIST; WEEKS 1987: 172). A rough calculation tells that, in six years, the Panama numbers add up to approximately 225,600 workers and 15,000 deaths, which results in a six percent mortality rate. Although critics had reasons to claim that Panama was "a mass grave," the MMR, like probably numerous other forgotten engineering projects scattered throughout the world, seems to have been far deadlier in comparison.

3. I consulted the Milstein Division of United States Local History and Genealogy at the New York Public Library as well as the National Archives section in New York. Merrill was born prior to the establishment of the Social Security numbering system which makes this information hard to find.

4. For different approaches to corporate photography, see for example Allan Sekula's 1978 essay "Dismantling Modernism: Reinventing Documentary (Notes on the Politics of Representation)" and Kevin Coleman's "local history of subaltern photography (2016).

5. Pinney (1997: 53) describes markers of typicality as visual elements that signal conformity with a category. 
6. There were groups who spoke Aruak (Arawak) languages in the region, but they were not in the immediate vicinity of the MMR (MALDI 1991: 211).

7. The origin of the name "Karipuna" is blurry, as with most ethnonyms given by whites to Amerindians. The anonymous author of the report of Francisco de Mello Palheta's expedition referred to a group called "Cavaripunna." Ricardo Franco d'Almeida Serra already talked about the "Caripuna" (1790: n.p.).

8. Deborah Poole (1997: 182) precisely describes indigenism as a "pan-Latin American intellectual movement whose stated goals were to defend the Indian masses and to construct regionalist and nationalist political cultures on the baess of what mestizo, and largely urban, intellectuals understood to be autochthonous or indigenous cultural forms." For more on indianismo, see Lilia Moritz Schwarcz, The Emperor's Beard: Dom Pedro II and the Tropical Monarchy of Brazil (2004).

9. Gibbon, Exploration of the Valley, insert between pages 294 and 295.

10. Aboriginal dog species in Rondônia, the cachorro-do-mato-de-orelha-curta (Atelocynus microtis), and the cachorro-do-mato-vinagre (Speothos venaticus) are medium-sized dogs, with short tail, dark hair, and small upstanding ears, have never been domesticated. They do not look like the animal in Gibbon's figure or the pup in Merrill's 768 photograph (VELDEN 2009).

11. R. S. S. "In Far-Away Bolivia," in "The Madeira-Mamoré in Rhyme and Blue-print," supplement to The Porto Velho Weekly Times (Jun. 6, 1909), 4-5.

12. "The Madeira-Mamoré Expeditions Collection," Firestone Library, Princeton University.

\section{ABSTRACTS}

The article examines how images, material culture, and texts intersect in the representation of the Karipuna, an indigenous group who lived in the Brazilian Amazon. I discuss how authors historically employed "markers of typicality" (PINNEY 1997) to signal the "purity" of the Madeira and Mamoré Valley's native population. I specifically focus on Dana Merrill's photographic documentation of the construction of the Madeira-Mamoré Railway, built in the region between 1907 and 1912. I analyze Merrill's corporate imagery in relation to the visualities of the Noble Savage. I argue that, although the photographer's gaze did follow elements that connoted the isolation of Amerindians, he was also interested in the hybrid reality of the Karipuna.

L'article examine comment les images, la culture matérielle et les textes se rencontrent et s'interpénètrent dans la représentation Karipuna, un groupe autochtone du sud-ouest de l'Amazonie brésilienne. Mon propos interroge l'approche historique des auteurs, notamment leurs utilisations des «marqueurs de la typicité» (PINNEY 1997) tels que les arcs et les flèches, les canots d'écorce et la nudité, pour signaler la «pureté» de la population autochtone de la vallée des rivières Madeira et Mamoré. Pour ce faire, je me concentre sur la documentation photographique faite par Dana Merrill lors de la construction du chemin de fer Madeira-Mamoré, une ligne de 320 kilometres construite dans la région entre 1907 et 1912. J'analyse l'imagerie corporative de Merrill par rapport aux représentations antérieures du Noble Sauvage. Je soutiens que, bien que le regard du photographe ait suivi des éléments qui suggéraient l'isolement des Amérindiens, ses images ambiguës enregistraient également la réalité hybride des Karipuna. 
INDEX

Mots-clés: photographie d'entreprise; marqueurs de typicité; Amazonie; indigénéité; Karipuna

Keywords: corporate photography; markers of typicality; Amazon; indigeneity; Karipuna

\section{AUTHOR}

MARIANA VON HARTENTHAL

Centro de Estudos da Imagem da América Latina (CECIAL) - Universidade Federal do Paraná 